\title{
“To Use or Not to Use-That Is the Question!" Using Facebook as an Educational Tool in Recreational Leadership Course
}

\author{
Muberra Celebi \\ Correspondence: Muberra Celebi, Abant Izzet Baysal University, Turkey. \\ Received: May 29, 2018 \\ doi:10.11114/jets.v6i7.3302 \\ Online Published: June 24, 2018 \\ URL: https://doi.org/10.11114/jets.v6i7.3302
}

\begin{abstract}
The purpose of this study was to examine the use of the Social networking site "Facebook" in "recreational leadership course" as an educational tool to facilitate the learning environment for sport management students. In this study qualitative research design and action research approach (emancipating/enhancing/critical science mode) were used. This research was based on the "by doing-experiencing" concept and focused on the usage of a Facebook group (as a closed group between students-lecturer/student-student) and on sharing course related topics inside and outside of the class under the supervision of the lecturer. The research was carried out with a total of 31 university students who participated in a "recreational leadership" elective course during the fall semester of 2015-2016. The data was collected both from the evaluation notes which were kept by the students at the end of the semester, and from observation notes of the researcher. According to the results based on the analysis of the evaluation notes of the students and the observation notes of the lecturer it appeared that "Facebook" as an educational tool in "recreational leadership course" was perceived mostly positive by students and the lecturer. In addition, according to the students' evaluation notes, four themes were established:

1. Personal Development, 2. Emotional Development, 3. Performance Development and 4. Cognitive Development. On the other hand, the analysis of the notes of the lecturer revealed four main themes as gains:

1. Improving the Quality of Class Management, 2. Systematic Application of Technology, 3. Improving the Quality of Education/Students, and 4. Learning by doing.
\end{abstract}

Keywords: social media, Social Networking Sites (SNS), Facebook (FB), recreational leadership course

\section{Introduction}

Recent technological developments have contributed a lot to every aspect of life. One of these developments has emerged in the internet environment. Social networking especially has become one of the most prominent developments. It has turned out to be a Social structure that people utilize anywhere and anytime. Thus, it is inevitable to benefit from Social networking with educational purposes. It has been possible to improve the quality of education, maintain sustainability, raise students' interests and engagement in the subjects by integrating Social networking into classrooms and activities outside classrooms. Social networking sites (SNS) allow students to experience new ways of learning. Facebook has become a popular Social networking site among young people worldwide, including university students. According to the STATISTA (2017) the most popular network worldwide as of September 2017, ranked by number of active accounts was Facebook. Market leader Facebook was the first Social network to surpass 1 billion registered accounts and even has 2.06 billion monthly active users. * 


\section{Leading social networks worldwide as of September 2017, ranked by} number of active users (in millions)

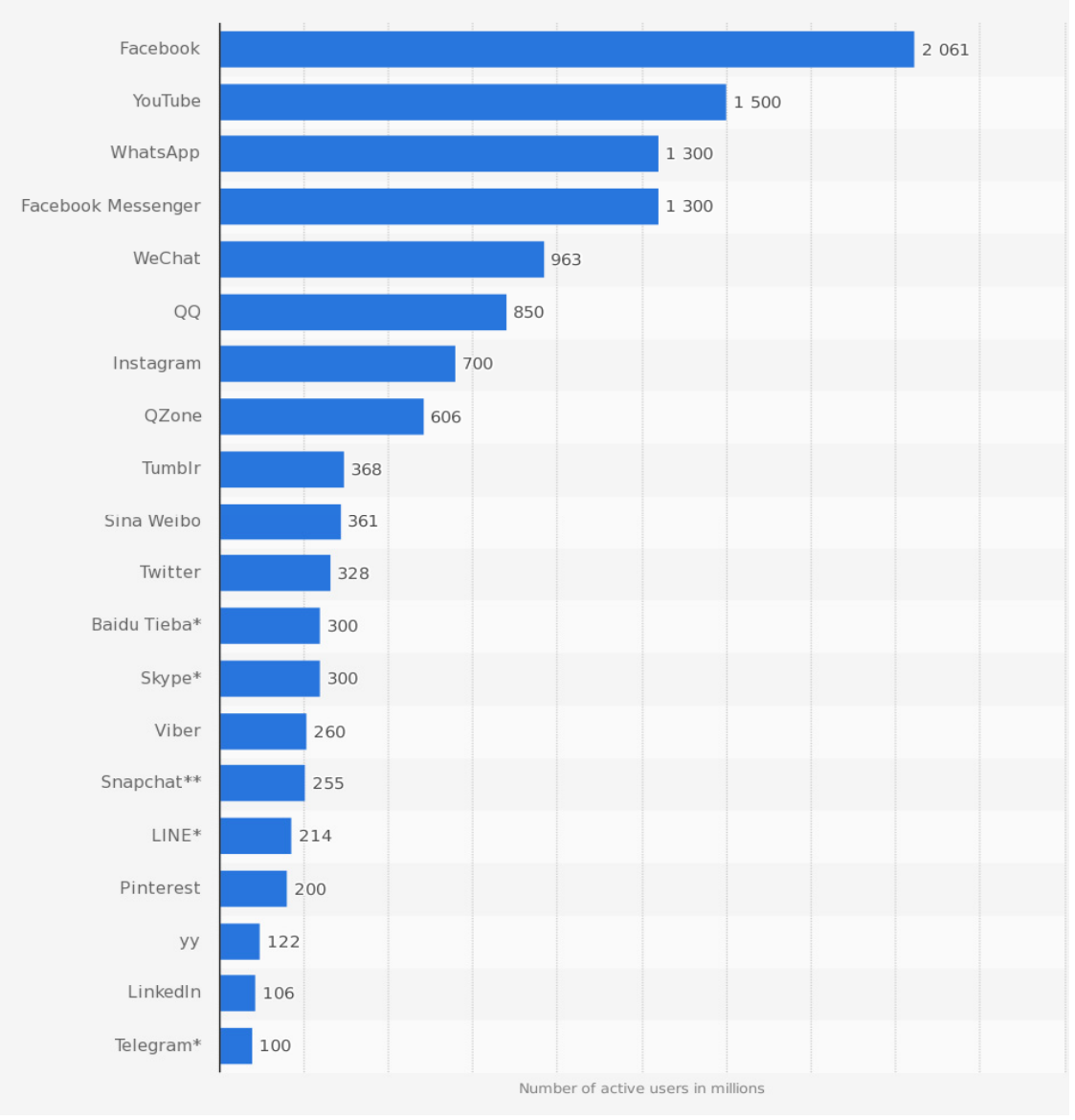

*Resource: Statista 2017: (retrieved: 19.11.2017)

However, the use of FB to support learning inside and outside the classroom may be a not yet fully exploited resource for instructors and students. Many academic studies revealed that a course supported by FB provides students with several benefits such as increasing sharing and cooperation, group work, strengthening communication between student-student and between student-faculty members, visualizing the content, drawing the attention and increasing the students' interest in the course. Pollara et al. (2011), Ozturk and Akgun (2012), Yapici and Hevedanli (2014), Manasijević et al. (2016), Orlanda-Ventayen and Ventayen (2017) also stated that most of the respondents in their study agreed that Social Media is useful in academic-related activities. Patrut et al. (2013) also claim that the valuable marketing tool FB recently began to shape as an educational platform. According to Kayri (2010) FB media not only makes lessons enjoyable but also provides lots of electronic material and builds collaboration in a group. Effective usage of SNS could be the best course assistant a lecturer has. Jones (2011) suggested that a professor can effectively adopt the microblogging tool "Twitter" which is another fast growing SNS, to inspire students to achieve a course's learning objectives, to eagerly anticipate and enjoy the classroom experience. Therefore he/she can make the learning experience richer and more satisfying for the students.

Creating a learning environment which motivates, inspires and encourages students to participate, to share, to collaborate while they are also enjoying is a dream of every educator at every level of education. Since students' engagement with their smart phones "all the time" including in the classes during the lectures, it is a disturbing new challenge of our era and almost impossible for educators to ignore. So why not use it as a tool? Developing a class group which is a form of virtual club on a SNS might encourage the online activity of students for learning purposes and focus on the course subjects. The teacher can act as an administrator, suggesting topics for discussion and posting links and in the meantime, giving and receiving feedback. Clements (2015) suggested in his study that FB is a useful tool for enhancing independent student engagement, as the amount and depth of engagement was highest with students engaging through FB. Similarly, according to the results of Esteves' study (2012); "Exploring Facebook to Enhance Learning and Student Engagement: A Case from the University of Philippines (UP) Open University", student 
engagement improved. It was verified by postings and continuous discussions and sharing even without being required by the professor. There were many student-led and student-initiated activities that continued even after the course was already finished. The idea of improving students' engagement in the course was supported by the study of Irwin et al. (2012). In their research they created individual "Facebook pages" for four university courses and used them to provide information relevant to the courses and allow opportunities for student interaction. The findings from this study indicated that "FB may be an appropriate addition to traditional e-learning tools, providing an integration of technology that is well received and used by today's students with an application that can be adapted to deliver content in a similar way to conventional learning management systems".

\section{Purpose}

In the light of the discussions given in the literature the purpose of this study was to examine the use of the Social networking site "Facebook" in "recreational leadership course" as an educational tool to facilitate learning environment for sport management students. The goal of the study was to determine the gains that students and the educator/lecturer perceived from the use of SNSs for educational purposes. The following research questions were used to guiding the design and implementation of this study:

1. What are the thoughts of the participating students at the end of the semester about using the SNS "Facebook" as an educational tool?

a. What are the thoughts of the students on the use of FB?

b. What are the students' gains perceived by using FB for educational purposes?

c. What are the thoughts of the students on continuing using FB?

2. What are the observations of the researcher (lecturer) during the semester about using the SNS "Facebook" as an educational tool and the gains of the students?

\section{Method}

\subsection{Research Design}

In this study qualitative research design and action research approach (emancipating/enhancing/critical science mode) were used. According to O'Brien (cited by: Aksoy, 2003), action research is to identify a problem by a group of people, to do something to solve the problem, to see how successful the efforts are, if the results are not satisfying to try to do it again, in short: learning by doing and experiencing. This research was based on the "by doing-experiencing" concept. The study focused on the usage of a FB group (as a closed group between students-lecturer/student-student) and on sharing course related topics inside and outside of the class under the supervision of the lecturer. The learning environment for this study was a "recreational leadership" elective course. The researcher (lecturer) worked in the group, not outside as an objective observer or external consultant. She contributed expertise when needed as a participant during the process (Pine, 2009). Therefore, this study was designed as an individual teacher Action Research approach (emancipating/enhancing/critical science mode which provides emancipation and enlightenment to the participant which leads to action and change. This mode helps participants to better understand fundamental problems during the process by raising their collective consciousness (Berg, 2001). Action Research approach helps participating students to gain new knowledge, skills and experience and helps them to develop a critical point of view to their own practices (Yildırım et al., 2013) through sharing a virtual interactive learning environment via a FB group which was created and supervised by the lecturer. According to Bradbury-Huang (2010) Action Research is a guide to build knowledge that comes along within a context of practice and requires researchers to work with practitioners. Demartini and Paoloni (2013) described also the aim of action research as to increase both researchers' and practitioners' understanding.

\subsection{Participants}

The research was carried out with a total of 31 (11 male, 20 female) university students who participated in a "recreational leadership" elective course during the fall semester (14 weeks) of 2015-2016. All the participants were third year undergraduate students of the Sport Management Department in The School of Physical Education and Sports at Abant Izzet Baysal University in Turkey.

Within the "Purposeful sampling" method: "Criterion sampling strategy" by selecting the participants with identified criteria: being registered to the "Recreational Leadership" elective course and being willing to use FB within a closed group, and "Convenience sampling strategy" were used. Due to the fact that the researcher is the instructor of the course and therefore having the participant-observer role in the research and the accessibility of the subjects (students) convenience sampling was the best method to use in this study. 


\subsection{Collecting Data}

The researcher worked in the group as the lecturer of a "recreational leadership" elective course and created a closed FB group at the beginning of the course. All the registered students were asked whether they would be willing to join the group and with consensus all students were added to the group as a member.

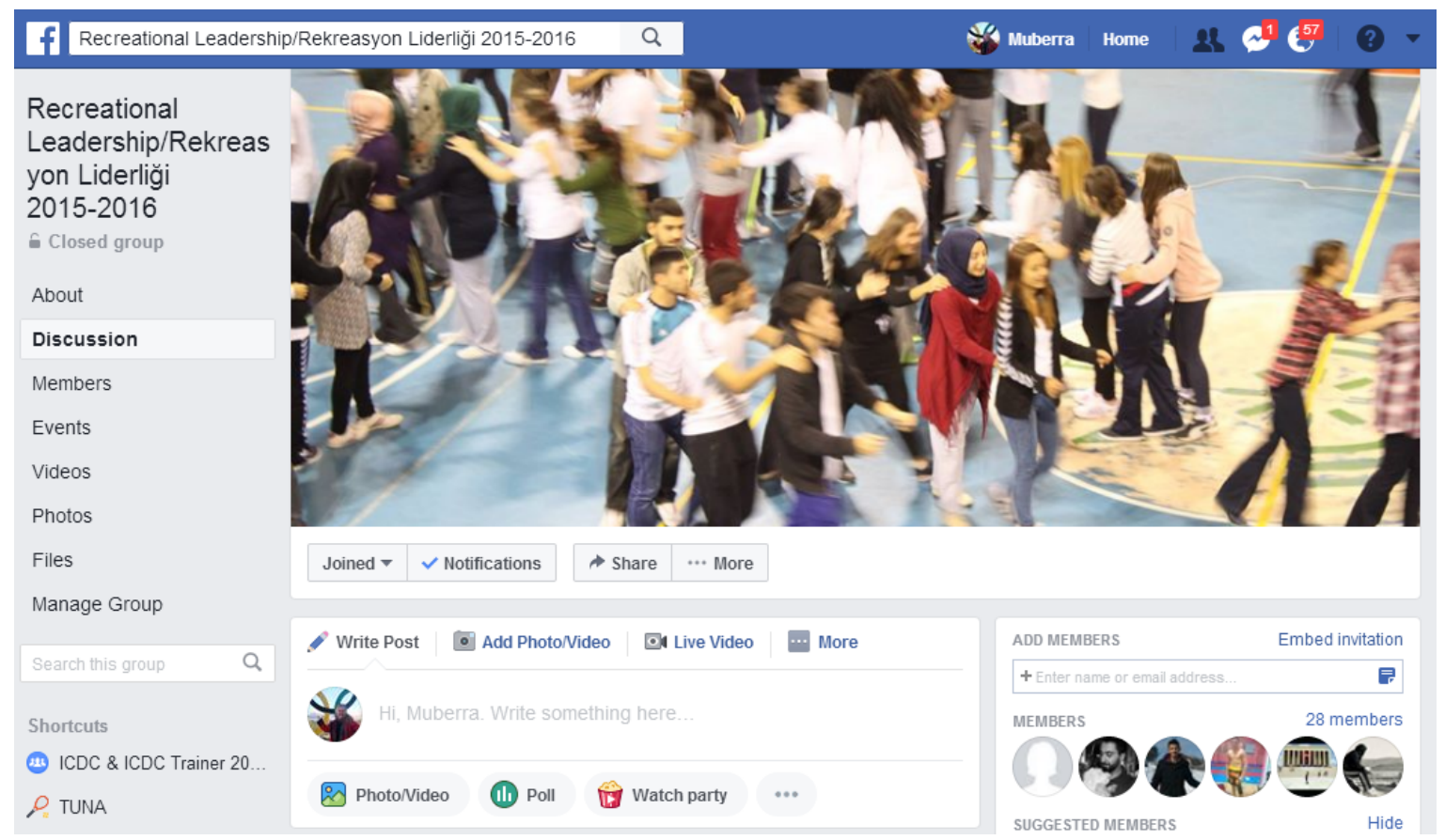

Picture 1. Facebook Closed group of 2015/2016 Recreational Leadership Course

The students were assigned to find various videos, articles and readings about recreational activities: examples of festivals, camps, special activities for children, elderly people and people with disabilities, etc. and to share them on the FB group wall. Sharing (posting) was mandatory for each student and the lecturer checked how many students followed these posts by using FB applications. The required documents, activities, information about the course contents and tasks needing to be done for using FB were given to the students in the course outline (Table 2). Within the scope of this course; lesson notes, announcements, presentations, videos, animations, links and assignments (organizing tournaments, trips, panels, spring festival etc. and posting this information, announcements, invitations and visual documents of the activities on the FB group wall) related to the course content were shared in the FB group. The course materials (Power Point presentations, related documents, assignments, etc.) were all downloaded as files on the FB group wall by the lecturer after each course. Students were prompted to explore sources through motivational speeches for FB usage during the semester by the lecturer. She challenged the students continuously to discuss related subjects and she actively used FB group as well. 


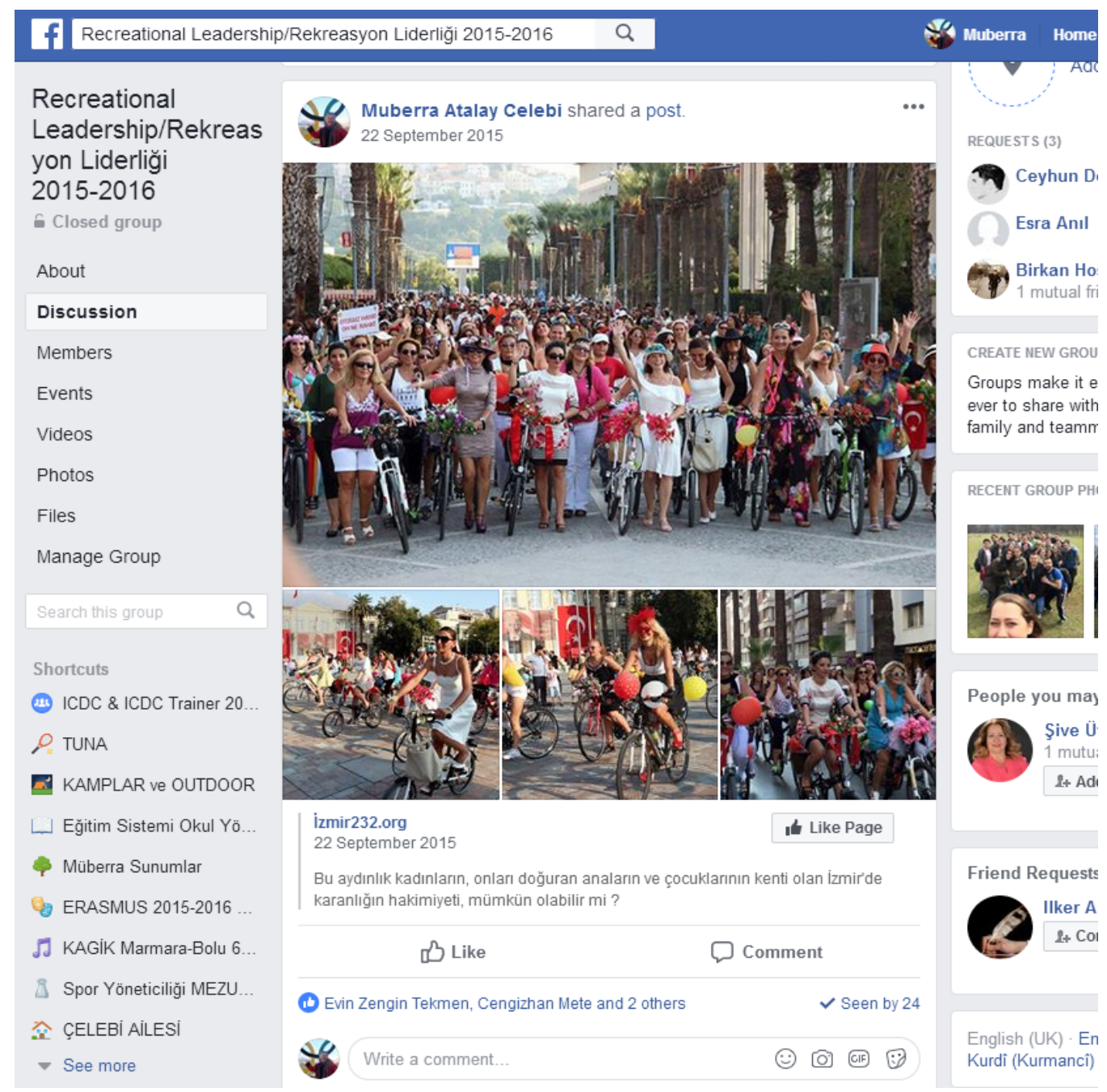

Picture 2. Examples of the interactions on Facebook group

Research data was collected in two different ways. The first one was the evaluation notes which were kept by the students at the end of the 14 weeks that expressed their thoughts and feelings about using FB as an educational tool. The second one was the observation notes of the researcher (lecturer) which were kept during the 14 weeks of the course period by the researcher. The participant-observer role of the researcher as a lecturer enabled the researcher to observe FB group activities before, during and after the course, to make interactive sharing with the students and to share feedback in the class. The researcher regularly wrote all related observation notes, i.e. after every course hour. The number of participants in data collection, information of students' evaluation notes and the observation notes of the lecturer are shown in Table1.

Table 1. The number of participants in data collection, information of students' evaluation notes and observation notes of the lecturer.

\begin{tabular}{|l|c|}
\hline \multicolumn{2}{|c|}{ TOTAL PARTICIPANTS IN THE RESEARCH } \\
\hline $\begin{array}{l}\text { TOTAL Number of } \\
\text { Participants }\end{array}$ & 31 Participants (11 Female- 20 Male) \\
\hline Department/Year & \multicolumn{2}{|c|}{ Sport Management/3rd year } \\
\hline \multicolumn{2}{|c|}{ PARTICIPANTS WHO KEPT EVALUATION NOTES } \\
\hline $\begin{array}{l}\text { Number of } \\
\text { Participants }\end{array}$ & 31 Participants \\
\cline { 2 - 3 } & \multicolumn{2}{|c|}{ 20 Pages A4 format } \\
\hline Number of pages & OBSERVATION NOTES \\
\hline \multicolumn{2}{|c|}{ 15 Pages A4 format } \\
Lecturer \\
Researcher)
\end{tabular}




\subsection{Course Outline and Action (Implementation) Course Plan}

The active participation "recreational leadership course" plan: the course plan and tasks and responsibilities of the students were provided by coordination of the researcher. Furthermore, in this action research a closed FB group was provided to the students to fulfill course related activities. It is important in action researches that the action to be taken is planned. Whilst planning pre-action, phases must be explained clearly during action and post-action. Table 2 . shows the course outline and the action (implementation) course plan in detail.

Table 2. The Outline and the Action (implementation) course plan of "Recreational Leadership" Course

\section{The Outline and the Action (implementation) course plan of "Recreational Leadership" Course}

Course Title: Recreational Leadership

\section{COURSE OUTLINE}

Type of course: Elective

Course contents:

Knowledge of basic leadership theories, definitions and new leadership approaches, comprehending and discus sing of relations hips between leadership types and recreational surroundings, analyzing and comparison of current leadership styles, experiencing leadership behaviors in recreational programming, managing and planning

\section{Objective(s) of the course :}

The aim of the course is to analyze the basic leadership theories, definition, new leadership approaches and leader types, comprehend and compare relationships between the leadership types and recreational fields. To make students experienced in leadership behaviors on the recreational activities planning, programming and managing.

Teaching and learning methods:

Direct method, using social media (Facebook) Presentations, discussions, questions and answers, group discussion and evaluation both in the class and on internet via Facebook closed group,

Practical Exam; organizing tournaments, trips, panels, spring festival etc.)

Project-Report, Periodic Evaluation (Self evaluation, group discussion and evaluation and observation notes of the students)

Assessment methods:

Homework, Group Projects and Presentations, Group discussion, quiz, Midterm and Final Exam

\section{ACTION PLAN}

(Course Application Plan with Social Network: Facebook usage)

\begin{tabular}{|c|c|c|}
\hline Phase & Technique & Description: Facebook Apps-Share \\
\hline Week 1-2 & $\begin{array}{l}\text {-Meeting with Class (ice-breaking) } \\
\text {-Giving the course content to the } \\
\text { students } \\
\text {-Climate of acceptance and activate } \\
\text { to use of facebook }\end{array}$ & $\begin{array}{l}\text { - To convince students to use FB and to get their } \\
\text { approval } \\
\text {-To establish a Facebook closed group and to invite } \\
\text { students into group } \\
\text { - Motivational speech for Facebook usage for the } \\
\text { course during whole semester, }\end{array}$ \\
\hline $\begin{array}{l}\text { Week } 3-4 \\
\text { Week } 5-6 \\
\text { Week } 7-8\end{array}$ & $\begin{array}{l}-1 \text { and } 2 \text {. Course subject Lecture } \\
-3 \text { and } 4 \text {. Course subject Lecture } \\
-5 \text { and } 6 \text {. Course subject Lecture } \\
-7 \text { and } 8 \text {. Course subject Lecture } \\
\text {-homework related to the course } \\
\text { subject } \\
\text {-questions-discussion, quiz.. }\end{array}$ & $\begin{array}{l}\text {-Sharing the past lecture in the Facebook group } \\
\text { (power-point verbal pres entation-related videos, } \\
\text { homeworks) } \\
\text { - Research and sharing as signment for the next les son } \\
\text {-Sharing next lecture in the Facebook group (power- } \\
\text { point verbal presentation-related videos, homeworks) }\end{array}$ \\
\hline Week 9-10 & $\begin{array}{l}\text { As ses sment: oral discussion, } \\
\text { presentation, critical thinking and } \\
\text { discussion, mid-term, quiz }\end{array}$ & $\begin{array}{l}\text { - Checking the sharings of related courses in the } \\
\text { Facebook group, eliminating deficiencies (completing } \\
\text { mis sing power-point verbal presentations-videos and } \\
\text { as signments) }\end{array}$ \\
\hline Week 11-12 & $\begin{array}{l}-9 \text { and } 10 . \text { Course subject Lecture } \\
\text { - Homework related to the course } \\
\text { subject } \\
\text {-questions-discussion, quiz... }\end{array}$ & $\begin{array}{l}\text {-Sharing the past lecture in the Facebook group } \\
\text { (power-point verbal pres entation-related videos, } \\
\text { homeworks) } \\
\text { - Research and sharing as signment for the next les on } \\
\text {-Sharing next lecture in the Facebook group (power- } \\
\text { point verbal presentation-related videos, homeworks) }\end{array}$ \\
\hline Week 13-14 & $\begin{array}{l}\text { Final As sesment: } \\
\text {-Summary of the complete subjects, } \\
\text {-Questions-answers-discus sion } \\
\text { - Solution of sample questions } \\
\text {-FINAL EXAM }\end{array}$ & $\begin{array}{l}\text {-Grading of pres entations, quizzes, presentations } \\
\text {-As signment of pas sing grades } \\
\text { - Sharing General grades in the Facebook group, }\end{array}$ \\
\hline
\end{tabular}




\subsection{Role of the Researcher}

The researcher has experience in qualitative studies for over 10 years and she gained academic knowledge and experience in qualitative research applications and analysis in the field. The course hours (3 hours/week) of 14 weeks enabled the researcher prolonged engagement with the students. These factors are thought to speed up and to bring practicality to the research. Furthermore, this participant-observer role helped the researcher to become a natural part of the qualitative study process and enabled the observation method to be applied and analysed efficiently. Whyte (1991) states that in Action Research approach the researcher continuously challenged by events and ideas, information and discussion presented by the research participants. Therefore, continuous learning is more efficient.

\subsection{Data Analysis}

The data was coded according to the themes and descriptive analysis and content analysis were used as qualitative analysis methods to analyse and interpret data. The obtained data was summarized and coded and patterns were established. All processes during analysing the data were carried out independently by two experts who are experienced in qualitative researches. The study was supported by some quotes from the views of the participant students. In these quotes students were coded as (A1, A2, K1, K2, etc.).

\subsection{Validity and Reliability}

Lincoln and Guba (cited by: Yıldirım et al. 2013) suggest using four aspects to ensure reliability and validity in qualitative researches: credibility, transferability, dependability and conformability. In this study for credibility (internal validity) triangulation and prolonged engagement strategies were used. Collecting data through students' notes and observation notes of the lecturer provided triangulation (Tobin et al.; Briller et al.; Bekhet et al. cited by: Yıldırım et al. 2013). In order to strengthen transferability (external validity), "Purposeful sampling" method and "Criterion sampling" strategies were used in this study. For dependability (internal validity) of the study (Erlandson et al. cited in: Yıldırım et al, 2013) the researcher took care of the consistency of the course activities from the beginning till the end and followed and recorded all activities of the students regularly. For the conformability of the research (external validity), all data collection tools, raw data, coding during data analysis were kept by the researcher to be able to re-analyse when this would be needed.

\section{Results}

The findings obtained from the results based on the analysis of evaluation notes of the students and the observation notes of the lecturer showed that "Facebook" as an educational tool in "recreational leadership course" was perceived mostly positive by both the students as well as the lecturer. The personal descriptions of the students and the lecturer about FB as an educational tool in "recreational leadership course" are shown in Figure 1. below respectively.

According to the students FB usage was: "a positive step", "a useful tool if it is used wisely and properly" and "an easy, fun and enjoyable course tool". According to the lecturer on the other hand, FB was: "the best assistant", "very easy to share and to communicate through it", and "practical in giving and receiving feedback". It was also mentioned that the closed FB group increased the active participation inside and outside of the class. According to the lecturer observation notes 26 of 31 students shared at least two posts twice a week on the FB group wall. 


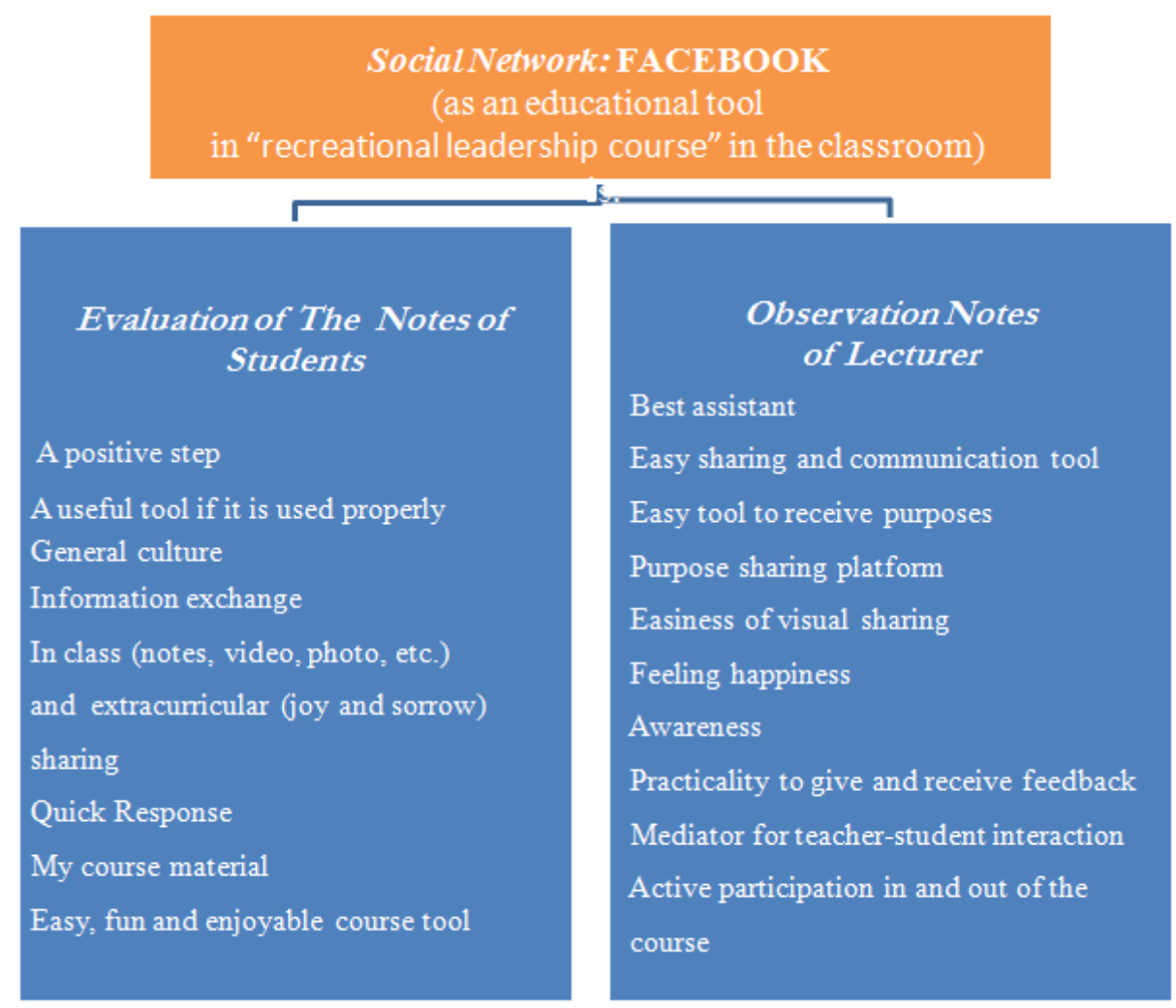

Figure1. Personal definitions of the students and the lecturer about FB as an educational tool in the "Recreational Leadership course"

The themes obtained from the research findings are presented separately for the evaluation notes of the students and the observation notes of the lecturer. In the figures, the themes related to the gains based on the students' evaluation notes and the observation notes of the lecturer are shown separately. In this way, it was much easier to see similar and different views of each of the parties involved. 


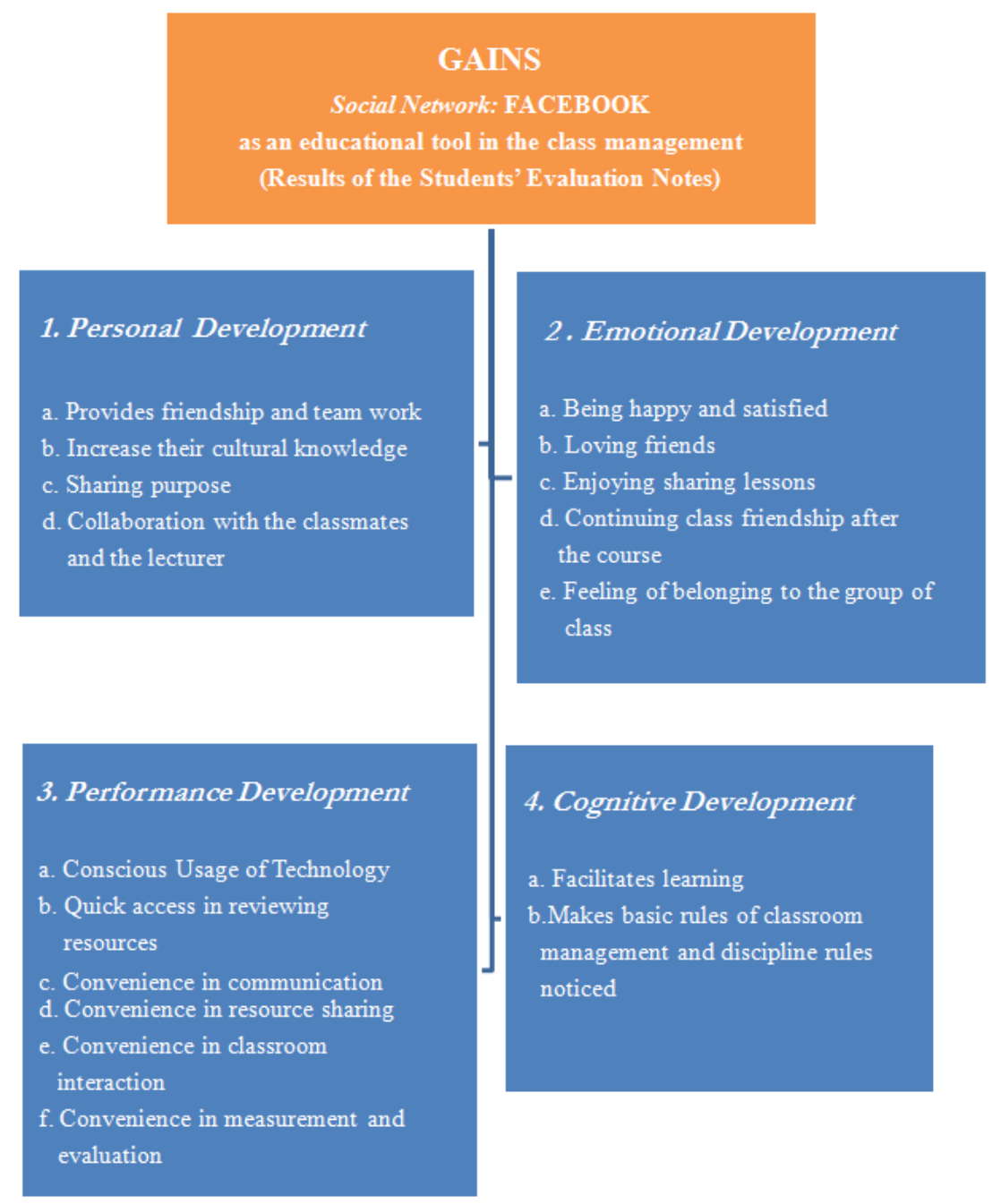

Figure 2. Themes Related to Gains by using FB as an educational tool in "recreational leadership course"

When we look at the results related to gains by using FB in the classroom according to the students' evaluation notes, four themes were revealed: 1. Personal Development, 2. Emotional Development, 3. Performance Development and 4. Cognitive Development.

Some of the expressions of the students related to first theme Personal Development were as follows:

"I see, and I am aware of things that I normally wouldn't look at" (K1). "This course gave me additional values because it was part of my life and my learning process constantly and in addition, continuing learning contributed a lot to me. I had immediate access to the information on my friends' assignments and sharing, and this FB page became my course material" (K30). "It is a useful tool that provides Social convergence when it is used purposefully. When I look at today, I see a communication tool which is used improperly by so many people, contrary to the real purpose... FB for the recreation leadership was a very useful tool for me. The group was created, and I had friends in this group whom I never met before, I had the opportunity to know them, to make good friendships and I learned a lot about recreation" (K23). "Thanks to this structure, we have had the opportunity to recognize recreational activities of different cultures and their characteristics. We have seen the events both nationally and internationally with its negative sides as well as positive sides. We learned the types and characteristics of recreation that we need individually and socially" (K31).

The students expressed their feeling about using FB as an educational tool in classroom management within the theme Emotional Development as follows:

"The course time was limited it was very good to share videos and texts on Social Media, I think it should be continued after the course" (K2). "We instantly share interesting things that we do not know about, texts and videos we like with our teachers and friends outside the classroom" (A4). "Sharing just 
among us made us feel like we were in the classroom environment" (A10). "The homework, presentation, research we did was not wasted. I saw that recreation is a very wide area... I think our group should remain and even be bigger, I still follow the page..." (K12). "It made the course easier and more fun..." (K21).

According to the students' evaluation notes the third theme was Performance Development. Some of these expressions were:

"It allowed us to see that "Social Media can be used to do beneficial things, not only to kill time" (K3).

"It is beneficial to use Social Media to get information, to examine the work of my friends, to be informed about the activities in advance... It is gratifying to use Social Media consciously, correctly and usefully against those who use unconsciously" (A11). "Creates a sharing environment outside the classroom" (K13). "Making the course a lot easier" (K14). "Communication, events, statistics and matches, sports follow-ups that some of us see and others not... It is logical and useful to activate FB in our class because we are now in the virtual world and even sports can be done in the virtual world now..." (K16). "FB allows us to reach all the resources any time we want" (K18). "It is very important for us to share internet online and use internet efficiently. All programs are one click away and this provides convenience..." (K25).

The fourth theme was Cognitive Development and the students expressed their opinions as follows:

"I was aware of everything when the lessons and activities were going on" (K19). "I find FB useful within the course context, we reach each other more easily, visual sharing is more effective for me, stays permanent in mind and everyone is using each other's knowledge" (K20). "An easy, fast and efficient sharing of course related materials and notifications, continuing the group after the lesson and continuing communication are all very helpful! (K22). "I did not use it anymore because I thought it was not attractive and a waste of time. But I started to use it again because I saw that it was used continuously in the context of the lesson and I thought it was useful sharing for the course. I was informed about the announcements" (K27). "Today, almost all Social Media tools are used ineffectively. The FB page we used for the course served a purpose for the first time for me. Quick accessibility makes it easy to access course activities and information" (K28).

The themes occurring according to the analysis of the notes of the lecturer as gains are shown in Figure 3 . The four main themes were: 1. Improving the Quality of Class Management, 2. Systematic Application of Technology, 3. Improving the Quality of Education/Students, and 4. Learning by doing.

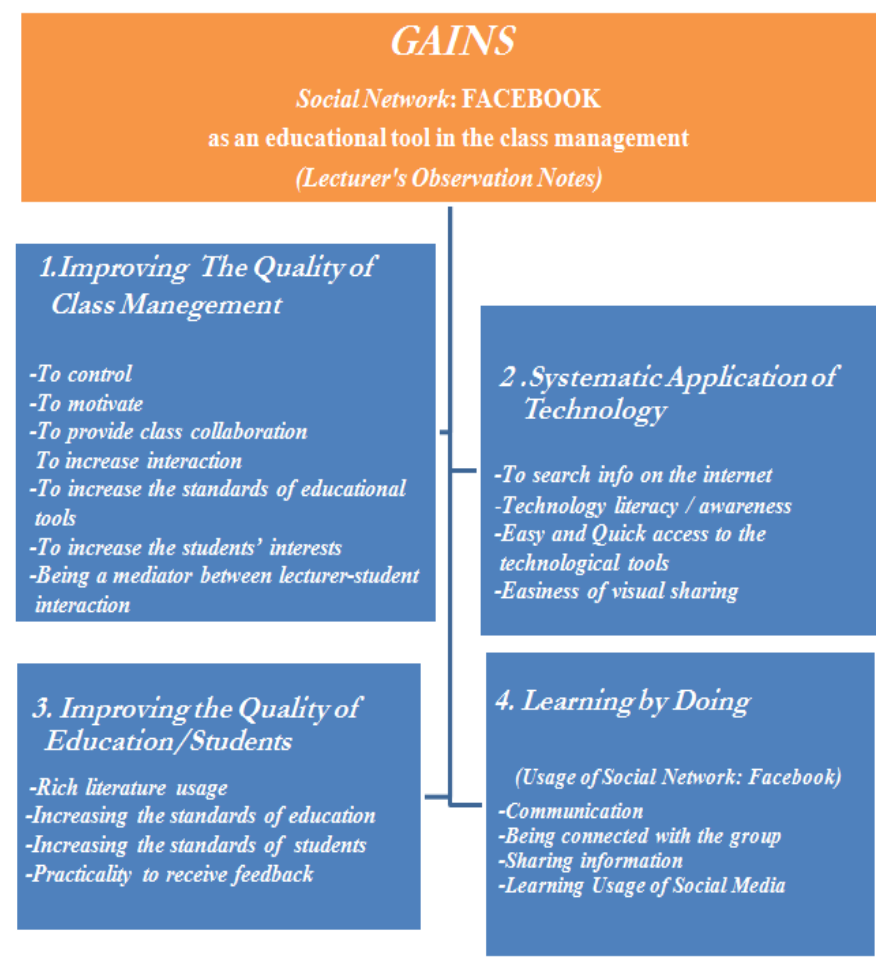

Figure 3. Themes Related to Gains by using FB as an education tool (Results of the Lecturer's Observation Notes) 
Some of the expressions of the Lecturer related to the first theme: 1. Improving the Quality of Class Management were:

"It was a great mediator between the students and me...". "It increased the students' interests and therefore interaction also increased". "It was easier to control the class and their assignments and also their reactions and comments over a discussion or a related video".

Lecturer expressed some of her thoughts about the $2^{\text {nd }}$ theme Systematic Application of Technology as follows:

"It was really easy and quick access to the technological tools. Nowadays almost every student has a smart or android phone, tablet or laptop! As a lecturer I had access to a very wide range of information related to the course subjects on internet and very interesting and amazing visual sharing". Improving the Quality of Education/Students was the $3^{\text {rd }}$ theme and according to the lecturer: "Using FB during the course increased the standards of education and thus the standards of the students...". "Practicality of giving and receiving feedback was remarkable!".

Some of the expressions of the Lecturer related to the 4th theme Learning by Doing were:

"Communication and being connected with the group were very easy and continued because the students were involved via internet all the time. They were learning by simply being part of the communication and sharing their thoughts...". "Social Media is a very important part of communication within young people's lives nowadays and they learned the usage of information carefully during the class. They had to consider the terms of use and privacy statements while they were sharing information, photos and videos of themselves or somebody else's...".

According to the notes of the lecturer at the end of semester the learning outcomes of the course were above average. There were only two students failing who did not follow the course at all. The notes of the researcher mentioning the actual learning outcomes were:

"It can be concluded that the students obtained a general knowledge about recreational programs. Students are now experienced in planning, preparing and implementing a recreational activity by conducting team work within the classroom. They shared their thoughts, photos and videos about those experiences by posting them on the Facebook group. It has even been observed that these exchanges and interactions continued after the end of the semester!".

\section{Discussion}

The results based on the analysis of the evaluation notes of the students and the observation notes of the lecturer showed that "Facebook" as an educational tool in "recreational leadership course" was perceived mostly positive by students and the lecturer. Gamble and Wilkins (2014) recommended educators keep an open mind about FB's educational value as overall students demonstrated positive attitudes toward its usefulness. They stated in their research that students specified essential class materials not being tied to time and place as one of the prime strengths of FB's educational potential. Chawinga's (2017) study also unveiled that students are not only ready and enthusiastic in using Social Media in the accomplishments of their educational activities but are also able to use Social Media practically. Students having difficulty in engaging discussions and in expressing their meanings in the class might be more easily communicative when they are online. Gamble and Wilkins (2014) stated similarly in their study that collaboration and interaction are key aspects of learning in higher education and thus Social networking tools can engage students who otherwise would not be a part of education experience. However, because of the informal basis of FB, the students may not necessarily perceive this as a formally planned element of the teaching and learning (Baran, 2010). The danger to be considered is that the students can be interested more in the social aspects than in the teaching features of FB. Similarly, Lu J. and Churchill D. (2014) argue in their study "Investigating the impact of social interactions among a class of undergraduate students on their learning engagement in a social networking environment" that high levels of cognitive engagement were not demonstrated in social interactions. However, they did not conclude that social networking environment had no effect on cognitive engagement at all; on the contrary students were able to access multiple perspectives, evaluate their tasks against others and be motivated to pay more attention to their tasks. Therefore, finding creative methods and ways to engage students in meaningful and intellectually stimulated learning is crucial but also challenging when designing a learning environment by using social media.

When we look at the results related to gains by using FB in the classroom according to the students' evaluation notes, four themes were revealed: 1. Personal Development, 2. Emotional Development, 3. Performance Development and 4. Cognitive Development. These results suggest that many students liked to be part of the group, to share ideas and knowledge, having variety of resources online and to have social interaction during the course and mostly to have fun. The results of Pollara et al.'s (2011) study also revealed that most students believed that they learned more because of using the group page and would like to use social networking for educational purposes. Similarly, Gamble and Wilkins' 
(2014) study showed that when activities are conducted within a learning community composed of peers, learners took an active role and exhibited more self-determination to improve their weakness until they were personally satisfied. The subjects in Atmaca's (2014) study concluded that positive features of FB in foreign language learning were many such as; increased motivation and engagement in the class and extensive resources which support our data as well.

The four main themes according to the analysis of the notes of the lecturer were: 1. Improving the Quality of Class Management, 2. Systematic Application of Technology, 3. Improving the Quality of Education/Students, and 4. Learning by doing. For an educator, one of the most challenging dimensions of using Social Media is providing a high level of educational environment for the students. It is very important to make an effective and an interactive course program for students as well as to be able to engage them. Barczyk and Duncan (2011) furthermore claim that "if tools (Social Media) are available to help better engage and educate students, they should be incorporated into the curriculum, not exclusively, but rather, in a supplemental fashion". Balakrishnan (2014) also found in his study that the integration of the various features of SNSs positively affects teaching and learning activities among students and lecturers in higher learning institutions. Our findings according to the course lecturer also revealed that the carefully designed course program not only improves both quality of class management and the quality of education but also saves time and money for both parties, encourages teamwork, increases productivity and motivates for further learning experiences (continuity), (Figure 5.).

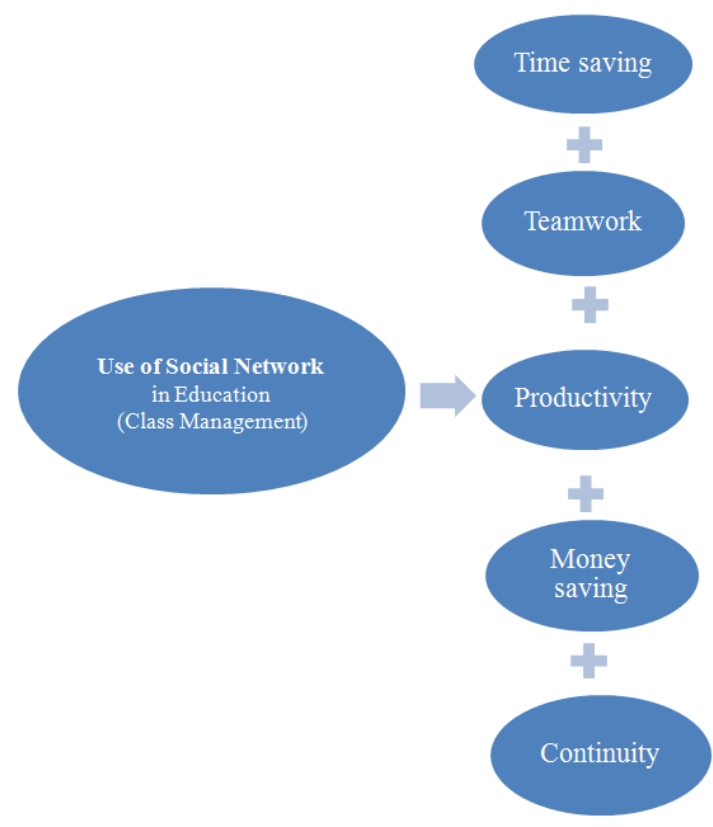

Figure 5. The Advantages of using Social Network as an educational tool

Systematic application of technology is another challenge both lecturers and students should consider. Social Media is a very important part of communication within young people's lives nowadays and they have to learn to use the information carefully during class. They had to consider the terms of use and privacy statements while they were sharing information, photos and videos of themselves or somebody else's. Wang Q. et al. (2012) in their study concluded that privacy and internet safety are very important challenges that should be considered in social learning environments. Barczyk and Duncan (2011) suggest for educators who want to use Social Media in their class to consider establishing institutional and/or personal guidelines. In that way teachers will be able to maximize the potential of social media-based learning while minimizing potential legal liability.

\section{Conclusion}

As a conclusion from an educator's point of view on usage of FB I can say that; especially for the courses with rich visual content such as "recreational leadership course"; sharing of videos, photos and activity examples by using FB takes students out of the routine and the monotonous sphere of the education process. It simply makes the class walls disappear. In addition, a FB group provides great convenience in sharing visuals, homework and course related materials for the educator. In that way the course becomes a platform by sharing the requirements (homework, quiz, exam etc.) of the course lessons through FB. The students receive course materials without spending extra costs like copying the documents, outlines, presentation papers, However, like all other technologies, using FB to support 
educational goals and to encourage students to use Social network sites in productive ways will be challenging. Instructors have to consider some issues such as ethics of using online materials, advertising purposes, technical support they might need, and whether they wish to rely on the cyber world to share all students work and teaching materials. While it's easy and exciting to exchange thoughts all over the web, teachers/lecturers must be particularly aware of the law and the restrictions in the country they are living in. It is also important to help protect students by making blogs/sites password protected and creating hidden profiles on FB.

Social networks that affect society so much are having effect on some of our behaviours and habits. As in many fields social network technologies also provide many opportunities in education. Social networks having many features and possibilities are helping teachers to support the learning process with the help of an active, a creative and a cooperative learning. They can also increase student-student, student-content and teacher-student interactions and support students to use and develop their researching, questioning and problem-solving skills in a productive way. Certainly the fact that the students who agreed to participate in this study have been asked to use FB actively at the beginning of the course and the fact that sharing/posting on the FB group was mandatory, might have had effect on the outcome of this research. However, it can be said that communication and interaction between the educator and the students have been carried out openly and sincerely both inside as well as outside the class during this study period. At this point it can be suggested that educators who want to use social networking sites as an educational tool should be cautious while using their "power" in their classroom. The motivation of the students and the sincerity in interactions are largely dependent on how the educator plays this role!

It is believed that the findings of this study can be used to promote the use of SNSs to improve teaching and learning experiences of both students and lecturers and also to increase communication and collaboration between them. Further research will be needed to explore more effective educational designs of Social Networking Sites for both students and lecturers. Furthermore, the study could be carried out with more participants from different fields in higher education.

The observations and conclusions reached in this study are limited to one class environment in one course semester and are based on the researcher's interpretations of facts. Therefore, generalising any of the findings should be done with care.

\section{References}

Aksoy, N. (2003). Action research: a method for improving and changing educational practices. Educational Administration in Theory \& Practice fall 2003, 36, 474-489.

Atmaca, Ç. (2014). To Facebook or Not To Facebook? International Journal of Arts \& Sciences, 7(6), 183-202.

Balakrishnan, V. (2014). Using social networks to enhance teaching and learning experiences in higher learning institutions, Innovations in Education and Teaching International, 51(6), 595-606. https://doi.org/10.1080/14703297.2013.863735

Baran B. (2010). Facebook as a formal instructional environment. British Journal of Educational Technology, 41(6), 146-149. https://doi.org/10.1111/j.1467-8535.2010.01115.x

Barczyk, C. C., \& Duncan, D. G. (2011). Social networking media as a tool for teaching business administration courses. International Journal of Humanities and Social Science, 1(17), 267-276.

Berg, B. L. (2001). Qualitative research methods for the social sciences (5th ed.). Allyn. and Bacon. Pub., 204.

Bradbury-Huang, H. (2010). What is good action research? Why the resurgent interest? Action Research, 8(1), 93-109. https://doi.org/10.1177/1476750310362435

Chawinga, D. W. (2017). Taking Social media to a university classroom: teaching and learning using Twitter and blogs. International Journal of Educational Technology in Higher Education, 14(3). https://doi.org/10.1186/s41239-017-0041-6

Clement J. C. (2015). Using Facebook to enhance independent student engagement: A Case study of first-year undergraduates. Higher Education Studies, 5(4). https://doi.org/10.5539/hes.v5n4p131

Demartini, P., \& Paoloni, P. (2013), Implementing an intellectual capital framework in practice, Journal of Intellectual Capital, 14(1), 69-83. https://doi.org/10.1108/14691931311289020

Esteves, K. K. (2012). Exploring Facebook to enhance learning and student engagement: A Case from the University of Philippines (UP) Open University. Malaysian Journal of Distance Education 14(1), 1-15.

Gamble, C., \& Wilkins, M. (2014). Student attitudes and perceptions of using Facebook for language learning. Dimension, 49-72. 
Irwin, C., Ball, L., Desbrow, B., \& Leveritt, M. (2012). Students' perceptions of using Facebook as an interactive learning resource at university. Australasian Journal of Educational Technology, 28(7), 1221-1232. https://doi.org/10.14742/ajet.798

Jones, A. (2011). "How Twitter Saved my Literature Class: A Case Study with Discussion." Teaching Arts and Science with the New Social Media. A collection edited by Charles Wankel. United Kingdom: Emerald Group Publishing Limited, 91-106. https://doi.org/10.1108/S2044-9968(2011)0000003008

Kayri, M., \& Çakir, Ö. (2010). An applied study on educational use of Facebook as a web 2.0 tool: The sample lesson of computer Networks and communication, International Journal of Computer Science \& Information Technology (IJCSIT), 2(4). https://doi.org/10.5121/ijcsit.2010.2405

Lu, J., \& Churchill, D. (2014). The effect of social interaction on learning engagement in a social networking environment. Interactive Learning Environments, 22(4), 401-417. https://doi.org/10.1080/10494820.2012.680966

Manasijević, D., Živković, D., Arsić, S., \& Milošević, I. (2016). Exploring students’ purposes of usage and educational usage of Facebook, Computers in Human Behavior, 60, July 2016, 441-450. https://doi.org/10.1016/j.chb.2016.02.087

Orlanda-Ventayen, C. C., \& Ventayen, R. J. M. (2017). E-Learning Role of Social Media in Education, 6th International Conference on Studies in Business, Management, Education and Law (SBMEL-17), Manila (Philippines) Sept. 18-19. ISBN 978-93-86878-01-4

Öztürk, M., \& Akgün, Ö. E. (2012). University students' purposes in using Social networking sites and their opinions on using these sites in education, Sakarya University Journal of Education, 2/3 December, 49-67.

Patrut, B., Patrut, M., \& Cmeciu, C. (2013). Social Media and the New Academic Environment: Pedagogical Challenges1st Edition, IGI Global Pub., US., 41. https://doi.org/10.4018/978-1-4666-2851-9

Pine, G. J. (2009). Teacher Action Research: Building Knowledge Democracies, SAGE Publications, Inc. DOI: http://dx.doi.org/10.4135/9781452275079.n11, (Retrieved: $\quad$ March 20, 2017). https://doi.org/10.4135/9781452275079.n11

Pollara, P., \& Zhu, J. (2011). Social Networking and Education: Using Facebook as an EduSocial Space. In Proceedings of Society for Information Technology \& Teacher Education International Conference, 3330-3338. Chesapeake, VA: AACE.

Statista (2017). http://www.statista.com/statistics/272014/global-Social-networks-ranked-by-number-of-users/ (Retrieved: 19.11.2017).

Wang, Q., Woo, H. L., Quek, C. L., Yang, Y., \& Liu, M. (2012). Using the Facebook group as a learning management system: An exploratory study. British Journal of Educational Technology, 43(3), 428-438. https://doi.org/10.1111/j.1467-8535.2011.01195.x

Whyte, W. F. E. (1991). Participatory Action Research. Sage Publications, Inc., 42. https://doi.org/10.4135/9781412985383

Yapıcı, İ. Ü., \& Hevedanl1, M. (2014). Educational use of Social networks: Facebook case study, European Journal of Research on Education, Special Issue: Educational Technology and Lifelong Learning, 16-21.

Yıldırım, A., \& Şimşek, H. (2013). Sosyal Bilimlerde Araştırma Yöntemleri, Seçkin Yayıncılık, Ankara.

\section{Copyrights}

Copyright for this article is retained by the author(s), with first publication rights granted to the journal.

This is an open-access article distributed under the terms and conditions of the Creative Commons Attribution license which permits unrestricted use, distribution, and reproduction in any medium, provided the original work is properly cited. 